ISSN: 2146-3042

DOI: $10.25095 /$ mufad.852148

\title{
VİOP 30 Vadeli İşlem Sözleşmesi ile Çeşitli Makroekonomik Faktörler Arasındaki İlişkinin İncelenmesi*
}

\author{
Yasemin KARATAŞ ELÇİÇEK ** \\ Koray KAYALIDERE***
}

\begin{abstract}
ÖZET
Vadeli işlem piyasasında yatırımcıların işlem yapabilecekleri sözleşmelerden birisi de futures sözleşmeleridir. Bu piyasalarda yatırımcllar portföy çeşitlendirme, hedging ve arbitraj seçeneklerinden herhangi birini kullanarak işlemlerini gerçekleştirebilmektedir. Dolayıslyla gerek portföy çeşitlendirme gerekse hedging ve arbitraj seçenekleri için işlem yapacakları sözleşmenin getirisini, işlem hacmini ve volatilitesini etkileyen faktörler yatırımcılar açısından önem arz etmektedir. Bu çalış̧ada VIOP 30 vadeli işlem sözleşmesinin getiri, işlem hacmi ve volatilite bazındaki dinamikleri ortaya çıkarılarak portföy yöneticilerinin performanslarını artırmalarına, riskten kaçınmak isteyen yatırmmcıların risklerini yönetebilmelerine katkı sağlamak amaçlanmaktadır. Bu nedenle çalışmanın amacı, vadeli işlem ve opsiyon piyasasinda işlem gören VIOP 30 vadeli işlem sözleşme getirisine, işlem hacmine ve volatilitesine etki eden makroekonomik faktörlerin incelenmesidir. Bu amaç doğrultusunda ilgili literatürden hareketle getiri, işlem hacmi ve volatiliteye etki etmesi beklenen 11 makroekonomik göstergenin ayllk frekansta verileri kullanılmıştır. Çok sayıda makroekonomik değişkenin tek bir çalışmada yer alması hem çalıșmayı literatürdeki diğer çalıșmalardan farklllaștırmakta hem de çalıșma sonuçlarından faydalanacak olan bilgi kullanicılarına önemli kolaylı sağlamaktadır. Bununla birlikte daha önce vadeli işlem sözleş̧meleri ile volatilite endeksi(VIX) ilişkisinin incelenmemiş olması ve özellikle yerli literatürde vadeli işlem sözleşmeleri ile makroekonomik faktörler arasındaki ilişsiyi inceleyen çalışma sayısının sinırlı sayıda olması nedeniyle çalıșmanın literatüre katkıda bulunacağı düşünülmektedir. Çalışmanın veri seti, Ocak 2013 -Aralık 2017 dönemi aylık verilerinden oluşmaktadır. Çalışmada, ileriye geriye dönük adımsal regresyon analizi kullanılmışıı. Çalışmanın bulgularında bazı makroekonomik değişkenlerin VIOP 30 vadeli işlem sözleşme getirisini, işlem hacmini ve volatilitesini etkilediğine dair istatistiksel olarak anlamlı sonuçlar elde edilmiştir. Çalışma sonuçlarının ileride yapılacak çalışmalara katkı sağlayacağı düşünülmektedir.

Anahtar Kelimeler: deli İşlem Sözleşmeleri, Getiri, İslem Hacmi, Volatilite

JEL Sintflandirmast: G15, G17, C32.
\end{abstract}

\begin{abstract}
Investigation of the Relationship Between ViOP 30 Futures Contract and Various Macroeconomic Factors

\section{ABSTRACT}

One of the contracts that investors can trade in the futures market is futures contracts. In these markets, investors are able to perform their transactions using any of the portfolio diversification, hedging and arbitrage options. Therefore, the factors affecting the return, trading volume and volatility of the contract for both portfolio diversification and hedging and arbitrage options are importance for investors. In this study, it is aimed to contribute to the performance of portfolio managers and to manage the risks of investors who want to avoid risk by revealing the dynamics of the VIOP 30 futures contract on the basis of return, volume and volatility. Therefore, the aim of this study is to examine macroeconomic factors affecting VIOP 30 futures contract return, volume and volatility traded in the futures and options market. For this aim, the monthly frequency data of 11 macroeconomic indicators, which are expected to affect returns, volume and volatility, were used based on the relevant literature. The fact that a large number of macroeconomic variables are included in a single study both differentiates the study from other studies in the literature and provides significant convenience to the users who will benefit from the study results. However, it is thought that the study will contribute to the literature since the relationship between futures contracts and volatility index (VIX) has not been examined before and the number of studies examining the relationship between the futures contracts and macroeconomic factors is limited. The data set of the study consists of monthly data for the period January 2013-December 2017. In the study, stepwise regression analysis was used as a method. The findings of the study, statistically significant results were obtained that some macroeconomic variables affect the return, volume and volatility of VIOP 30 futures contracts, but no significant results with some variables. We believe that the study findings will contribute to the literature.

Keywords: Futures contracts, Return, Volume, Volatility

Jel Classification: G15, G17, C32.
\end{abstract}

\footnotetext{
* Bu çalışma, Manisa Celal Bayar Üniversitesi Sosyal Bilimler Enstitüsü İşletme Anabilim Dalı Muhasebe Finansman Programı'nda Doç. Dr. Koray KAYALIDERE danışmanlığında Yasemin KARATAŞ ELÇiçEK tarafindan tamamlanan doktora tezinin bir parçasıdır.

Makale Gönderim Tarihi: 19. 02.2020, Kabul Tarihi: 29.05.2020, Makale Türü: Nicel Araştırma

** Dr., Siirt Üniversitesi, Sosyal Bilimler Meslek Yüksekokulu, yaseminkaratas@siirt.edu.tr, ORCID: 00000001-7423-5839

*** Doç. Dr., Manisa Celal Bayar Üniversitesi, İktisadi ve İdari Bilimler Fakültesi, koray.kayalidere@cbu.edu.tr, ORCID: 0000-0003-4073-1644.
} 


\section{GíRiş}

Yatırımcıların birikimlerini sermaye piyasalarında değerlendirmeye başlamalarıyla birlikte risk-getiri ilişkisi önem kazanmıştır. Bu bağlamda yatırımcılar mümkün olduğunca risklerini minimize etmenin, getirilerini ise maksimize etmenin yollarını araştırmaya başlamışlardır.

Yatırımcıların spot piyasalarda gerçekleştirmiş oldukları yatırımların varlık fiyatlarındaki dalgalanmalar nedeniyle risk taşıması, yatırımcıları portföy çeşitlendirmesinin öncesinde söz konusu riskleri kontrol altına almaya yönlendirmiştir. Vadeli işlem piyasalarının kuruluş amaçları incelendiğinde, yatırımcıların gelecekte karşılaşabileceği olası fiyat dalgalanmalarına karşı yatırımlarını koruyabilmesine imkân sağladığı görülmektedir. Bununla birlikte, vadeli işlem piyasalarında işlem yapan yatırımcılar sadece riske karşı korunma avantajı sağlamakla kalmaz, aynı zamanda spekülasyon ve arbitraj imkanına da sahip olurlar. Vadeli işlem (futures) sözleşmeleri, belirli nitelikteki ve miktardaki bir malın veya finansal enstrümanın bugünden belirlenmiş bir fiyat üzerinden gelecekteki bir tarihte teslim edilmesini ya da teslim alınmasını hükme bağlayan yasal finansal araçlardır (Ceylan ve Korkmaz, 2008:279). Vadeli işlem sözleşmelerinin işlem maliyetinin düşük olması, kaldıraç etkisinin bulunması ve yüksek likiditeye sahip olması piyasadaki kullanışlı bilgilerin spot piyasalarla kıyaslandığında, vadeli işlem piyasalarına daha hızlı ulaşmasını sağlamakta ve bu durum vadeli işlem piyasalarındaki bilgi etkinliğini artırmaktadır (Chance ve Brooks, 2010:14, Çelik,2012:7).

Vadeli işlem piyasalarının risk yönetimi, geleceğe yönelik fiyat keşfi, işlemsel avantaj ve kaldıraç etkisi ile piyasa etkinliği olmak üzere dört temel fonksiyonu bulunmaktadır (Chance ve Brooks, 2010: 1-2). Yatırımcılar açısından önemli avantajlar sağlayan vadeli işlem sözleşmelerinin özellikle son zamanlarda tercih edilme oranlarının yükselmesi bu sözleşmeleri getiri, işlem hacmi ve volatilite bazında etkileyen faktörlerin neler olduğu konusuna yönelik ilgiyi artırmıştır. Ulusal literatür incelendiğinde vadeli işlem sözleşmeleri ile makroekonomik değişkenler arasındaki ilişkiyi inceleyen sınırlı sayıda araştırmaya rastlanmaktadır. $\mathrm{Bu}$ durum, vadeli işlem sözleşmeleri ile makroekonomik değişkenler arasındaki ilişkinin incelendiği çalışmalara ihtiyaç duyulduğunu göstermektedir. Bununla birlikte çok sayıda makroekonomik değişkenin tek bir çalışmada yer alması hem çalışmayı literatürdeki diğer çalışmalardan farklılaştırmakta hem de çalışma sonuçlarından faydalanacak olan bilgi kullanıcılarına önemli kolaylık sağlamaktadır. Aynı zamanda daha önce vadeli işlem sözleşmeleri ile volatilite endeksi(VIX) ilişkisinin incelenmemiş olması nedeniyle de çalışmanın literatüre katkıda bulunacağı düşünülmektedir. Bu nedenle çalışmada Vadeli İşlem ve Opsiyon Piyasasında yüksek işlem hacmine sahip olan VİOP 30 (BİST 30 endeks vadeli işlem sözleşmesi) vadeli işlem sözleşmesini getiri, işlem hacmi ve volatilite bazında etkileyen makroekonomik faktörlerin incelenmesi amaçlanmaktadır. Çalışmanın incelenen sözleşmenin getiri, işlem hacmi ve volatilite bazındaki dinamiklerini ortaya çıkararak portföy yöneticilerinin performanslarını artırmalarına, riskten kaçınmak isteyen yatırımcıların risklerini yönetebilmelerine katkı sağlayacağı öngörülmektedir.

\section{LITERATÜR}

Vadeli işlem sözleşmeleri ile makroekonomik faktörler arasındaki ilişkinin araştırıldığı çalışmalar incelendiğinde yerli literatürde konuya ilişkin çalışmanın sayıca sınırlı olduğu, 
çalışmaların çoğunlukla spot piyasalarda yoğunlaştığı; yabancı literatürde ise daha çok makroekonomik haber duyurularının vadeli işlem sözleşmeleri üzerindeki etkisinin incelendiği görülmektedir. Dolayısıyla yapılan çalışma, vadeli işlem piyasalarına yönelik olması, incelenen dönemin vadeli işlem sözleşmelerine ilişkin işlem hacimlerinin yükseldiği 2012 sonrasını kapsaması, çalışmada çok sayıda makroekonomik değişkenin yer alması ve daha önce vadeli işlem sözleşmeleri ile volatilite endeksi (VIX) ilişkisinin incelenmemiş olması gibi faktörlerden dolayı literatürdeki çalışmalardan farklılaşmaktadır. Bununla birlikte çalışmada VİOP 30 vadeli işlem sözleşmesine dair yalnızca getiri bazında değil, aynı zamanda işlem hacmi ve volatilite bazındaki makroekonomik dinamiklerin belirlenmeye çalışılmasının da literatüre katkı sağlayacağ öngörülmektedir. Aşağıdaki tabloda literatürde yer alan bazı çalışmalara yer verilmiştir.

Tablo 1. Literatürde vadeli işlem sözleşmeleri ve spot piyasa ile makroekonomik faktörler arasındaki ilişkinin araştırıldığ 1 çalışmalar

\begin{tabular}{|c|c|c|c|c|c|}
\hline $\begin{array}{l}\text { Araştırmacının } \\
\text { Adı }\end{array}$ & $\begin{array}{l}\text { İncelenen } \\
\text { Piyasa }\end{array}$ & $\begin{array}{l}\text { Bağımlı } \\
\text { Değișkenler }\end{array}$ & Bağımsız Değişkenler & $\begin{array}{l}\text { İncelenen } \\
\text { Dönem }\end{array}$ & $\begin{array}{l}\text { Kullanılan } \\
\text { Yöntem }\end{array}$ \\
\hline $\begin{array}{l}\text { Ederington ve } \\
\text { Lee (1993) }\end{array}$ & $\begin{array}{l}\text { Döviz ve Faiz } \\
\text { Vadeli İşlem } \\
\text { Sözleşmesi }\end{array}$ & $\begin{array}{l}\text { Getiri } \\
\text { Volatilite }\end{array}$ & $\begin{array}{l}\text { Gayrisafi milli hâsıla, } \\
\text { istihdam, enflasyon ve } \\
\text { büyüme ile ilgili haberler }\end{array}$ & $\begin{array}{l}\text { Kasım } 1988 \\
\text { ile } 29 \text { Kasım } \\
1991\end{array}$ & Regresyon \\
\hline $\begin{array}{l}\text { Clare ve } \\
\text { Courtenay } \\
(2001)\end{array}$ & $\begin{array}{l}\text { Faiz, Endeks ve } \\
\text { Döviz } \\
\text { Vadeli İşlem } \\
\text { Sözleşmesi }\end{array}$ & Volatilite & $\begin{array}{l}\text { Faiz oranı haberleri de } \\
\text { dahil olmak üzere pek çok } \\
\text { makroekonomik haber ve } \\
\text { İngiltere Merkez } \\
\text { Bankasının operasyonel } \\
\text { bağımsızlık öncesi-sonrası } \\
\text { karşılaştırılması }\end{array}$ & $\begin{array}{l}\text { Ocak 1994- } \\
\text { Haziran } 1999\end{array}$ & $\begin{array}{l}\text { Kruskal } \\
\text { Wallis }\end{array}$ \\
\hline $\begin{array}{l}\text { Andersson vd } \\
(2009)\end{array}$ & $\begin{array}{l}\text { Almanya uzun } \\
\text { vadeli hazine } \\
\text { tahvilleri }\end{array}$ & $\begin{array}{l}\text { Fiyat } \\
\text { Getiri }\end{array}$ & $\begin{array}{l}44 \text { makroekonomik haber } \\
\text { ve Avrupa Merkez Bankası } \\
\text { Para Politikası }\end{array}$ & $\begin{array}{l}\text { Ocak1999- } \\
\text { Aralık } 2005\end{array}$ & $\begin{array}{l}\text { Yarı } \\
\text { parametrik } \\
\text { model }\end{array}$ \\
\hline $\begin{array}{l}\text { Chevallier } \\
\text { (2009) }\end{array}$ & $\begin{array}{l}\text { Emtia Vadeli } \\
\text { İşlem } \\
\text { Sözleşmesi }\end{array}$ & Getiri & $\begin{array}{l}\text { Makroekonomik faktörler, } \\
\text { Enerji Faktörleri ve } \\
\text { Kurumsal Faktörler }\end{array}$ & $\begin{array}{l}22 \text { Nisan } \\
2005-1 \text { Ekim } \\
2008\end{array}$ & TGARCH \\
\hline $\begin{array}{l}\text { Zügül ve Şahin } \\
\text { (2009) }\end{array}$ & $\begin{array}{l}\text { Hisse Senedi } \\
\text { Piyasası }\end{array}$ & Getiri & $\begin{array}{l}\text { Dolar döviz kuru, M1 para } \\
\text { arzı, faiz oranı ve tüketici } \\
\text { fiyat endeksi }\end{array}$ & $\begin{array}{l}\text { Ocak 2004- } \\
\text { Aralık } 2008\end{array}$ & $\begin{array}{l}\text { Doğrusal } \\
\text { Regresyon } \\
\text { Analizi }\end{array}$ \\
\hline $\begin{array}{l}\text { Batten vd. } \\
\text { (2010) }\end{array}$ & $\begin{array}{l}\text { Emtia Vadeli } \\
\text { İşlem } \\
\text { Sözleşmesi }\end{array}$ & Volatilite & $\begin{array}{l}\text { İş dünyası, Parasal } \\
\text { Değişkenler ve Finansal } \\
\text { Piyasalar Girişimi }\end{array}$ & $\begin{array}{l}\text { Ocak } 1986 \\
\text { ile May1s } \\
2006\end{array}$ & $\begin{array}{l}\text { Blok } \\
\text { Dişsallık } \\
\text { Nedensellk } \\
\text { Testi }\end{array}$ \\
\hline Vrugt (2010) & Hazine Bonosu & Getiri & $\begin{array}{l}\text { Reel ekonomi, İstihdam, } \\
\text { Tüketim, Fiyatlar, İleriye } \\
\text { dönük beklentiler, Federal } \\
\text { Açı Piyasa Komitesi } \\
\text { (FOMC) haberleri, Net } \\
\text { İhracat ve Devlet Bütçesi } \\
\text { başlığı altında } 27 \\
\text { makroekonomik haber }\end{array}$ & $\begin{array}{l}\text { Ocak } 1996 \text { - } \\
\text { Aralık } 2016\end{array}$ & Regresyon \\
\hline
\end{tabular}




\begin{tabular}{|c|c|c|c|c|c|}
\hline $\begin{array}{l}\text { Pen ve Sévi } \\
\text { (2011) }\end{array}$ & $\begin{array}{l}\text { Petrol Vadeli } \\
\text { İşlem } \\
\text { Sözleşmesi }\end{array}$ & Getiri & $\begin{array}{l}\text { Gelişmiş ve Gelişmekte } \\
\text { olan ülkelerden alınan } 187 \\
\text { gerçek (reel) ve nominal } \\
\text { makroekonomik duyuru }\end{array}$ & $\begin{array}{l}\text { Kasım 1993- } \\
\text { Mart } 2010\end{array}$ & $\begin{array}{l}\text { Yaklaşık } \\
\text { Faktör } \\
\text { Analizi }\end{array}$ \\
\hline $\begin{array}{l}\text { Aktaş ve Akdă̆ } \\
\text { (2013) }\end{array}$ & $\begin{array}{l}\text { Hisse Senedi } \\
\text { Piyasası }\end{array}$ & Fiyat & $\begin{array}{l}\text { Mevduat faiz oranı, TÜFE, } \\
\text { dolar kuru, euro kuru, } \\
\text { işsizlik oranı, sanayi } \\
\text { üretim endeksi, ihracat } \\
\text { tutarı, kapasite kullanım } \\
\text { oranları, altın fiyatları, } \\
\text { tüketici güven endeksi ve } \\
\text { ham petrol }\end{array}$ & 2008-2012 & $\begin{array}{l}\text { Çoklu } \\
\text { Doğrusal } \\
\text { Regresyon } \\
\text { Analizi ve } \\
\text { Granger } \\
\text { Nedensellk } \\
\text { Testi }\end{array}$ \\
\hline $\begin{array}{l}\text { Özgümüsş vd } \\
\text { (2013) }\end{array}$ & $\begin{array}{l}\text { Endeks ve } \\
\text { Döviz Vadeli } \\
\text { İşlem } \\
\text { Sözleşmesi }\end{array}$ & $\begin{array}{l}\text { Getiri } \\
\text { İşlem Hacmi } \\
\text { Volatilite }\end{array}$ & $\begin{array}{l}\text { Altın, Büyüme, Bütçe } \\
\text { açı̆̆ı/GSYİH, Cari } \\
\text { Açı/GSYİH, enflasyon, } \\
\text { faiz, ihracat, ithalat, para } \\
\text { arzı ve S\&P } 500 \text { endeks }\end{array}$ & $\begin{array}{l}\text { Şubat } 2005 \text { - } \\
\text { Kasım } 2011\end{array}$ & Regresyon \\
\hline $\begin{array}{l}\text { Chia ve Lim } \\
(2015)\end{array}$ & $\begin{array}{l}\text { Hisse Senedi } \\
\text { Piyasası }\end{array}$ & Fiyat & $\begin{array}{l}\text { Sanayi üretim endeksi, } \\
\text { enflasyon, para arzı, faiz } \\
\text { oranları ve döviz kuru }\end{array}$ & $1980-2011$ & ARDL \\
\hline $\begin{array}{l}\text { Çetin Demir } \\
(2015)\end{array}$ & $\begin{array}{l}\text { Endeks Vadeli } \\
\text { İşlem } \\
\text { Sözleşmesi }\end{array}$ & Fiyat & $\begin{array}{l}\text { M2, enflasyon, GSYİH, } \\
\text { döviz kuru, cari işlemler } \\
\text { dengesi, piyasa faiz oranı, } \\
\text { sanayi üretim endeksi, } \\
\text { S\&P } 500 \text { endeksi, risk } \\
\text { primi ve altın }\end{array}$ & $\begin{array}{l}2006 \mathrm{Q} 1- \\
2014 \mathrm{Q} 2\end{array}$ & Regresyon \\
\hline Özdemir (2017) & $\begin{array}{l}\text { Dolar Vadeli } \\
\text { İşlem } \\
\text { Sözleşmesi }\end{array}$ & Fiyat & $\begin{array}{l}\text { Dolar kuru, ihracat, ithalat, } \\
\text { altın, faiz oranı, sanayi } \\
\text { üretim endeksi ve tüketici } \\
\text { fiyat endeksi }\end{array}$ & $\begin{array}{l}\text { Ocak 2005- } \\
\text { Aralık } 2016\end{array}$ & $\begin{array}{l}\text { Granger } \\
\text { Nedensellk } \\
\text { Testi }\end{array}$ \\
\hline Perçin (2019) & $\begin{array}{l}\text { Hisse Senedi } \\
\text { Piyasası }\end{array}$ & Volatilite & $\begin{array}{l}\text { Para arzı, döviz kuru. faiz } \\
\text { oranı }\end{array}$ & $2008-2017$ & $\begin{array}{l}\text { Vektör } \\
\text { Otoregresyon } \\
\text { (VAR) }\end{array}$ \\
\hline $\begin{array}{l}\text { Durmuş vd. } \\
\text { (2019) }\end{array}$ & $\begin{array}{l}\text { Hisse Senedi } \\
\text { Piyasası }\end{array}$ & Getiri & $\begin{array}{l}\text { Mevduat faiz oranı, dolar } \\
\text { kuru, euro kuru, enflasyon } \\
\text { oranı ve altın fiyatları }\end{array}$ & $\begin{array}{l}\text { Mayıs 2006- } \\
\text { Ekim } 2018\end{array}$ & $\begin{array}{l}\text { Vektör } \\
\text { Otoregresyon } \\
\text { (VAR) }\end{array}$ \\
\hline $\begin{array}{l}\text { Fattah ve } \\
\text { Kocabiyık } \\
(2020)\end{array}$ & $\begin{array}{l}\text { Hisse Senedi } \\
\text { Piyasası }\end{array}$ & Fiyat & $\begin{array}{l}\text { TÜFE, SÜE, Faiz Oranı, } \\
\text { Para Arzı, İhracatın İthalatı } \\
\text { Karşılama } \\
\text { Oranı, Dolar Kuru, Altın } \\
\text { ve Ham Petrol fiyatı }\end{array}$ & $\begin{array}{l}\text { Ocak 2010- } \\
\text { Şubat } 2019\end{array}$ & $\begin{array}{l}\text { Toda } \\
\text { Yamamoto }\end{array}$ \\
\hline
\end{tabular}

Ederington ve Lee (1993) çalışmalarının sonuçlarında döviz vadeli işlem sözleşme getirilerinin mal ticareti, istihdam, gayrisafi milli hâsıla ve perakende satışlara karşı duyarlılık gösterdiği; faiz vadeli işlem sözleşme getirilerinin ise enflasyon, istihdam ve dayanıklı mal siparişlerine karşı duyarlı olduğu ifade edilmiştir. Bunun yanında tüketici fiyat endeksi, üretici fiyat endeksi ve istihdam verilerine dair haberlerin volatiliteyi etkileme süresinin diğer değişkenlerle kıyaslandığında daha uzun olduğu, fiyat değişimlerinin bir dakika içinde 
meydana geldiği ve ilk on beş dakika içerisinde volatilitenin normal seyrinin üzerinde olduğu bilgileri de çalışmanın sonuçları arasında yer almaktadır.

Clare ve Courtenay (2001) çalışmalarının sonuçlarında üç futures sözleşmesinin de bağımsızlık dönemi sonrasındaki faiz oranı duyurularına bağımsızlık öncesi döneme göre daha yüksek reaksiyon gösterdiği fakat bu reaksiyonun on dakika sonra düştügü belirtilmiştir. Bununla birlikte faiz açıklamalarının ardından ilk beş dakikada faiz oranı sözleşmelerinin volatilitelerinin arttığ fakat bu durumun FTSE-100 ve döviz kuru sözleşmeleri için geçerli olmadığı ifade edilmiştir. Diğer makroekonomik duyurular ile ilgili sonuçlarda ise LIFFE sözleşmelerinin banka bağımsızlık dönemi sonrası bu duyurulara verdiği tepkilerin banka bağımsızlık öncesi tepkilere göre daha düşük olduğu, ancak döviz sözleşmelerinde durumun tam tersi olduğu belirtilmiştir.

Andersson vd. (2006) çalışmalarının sonuçlarında, Avrupa'ya ilişkin haberlerin genellikle Amerika Birleşik Devletleri'ndeki haberlerle aynı nitelikteki haberlerden sonra ortaya çıktığı belirtilmiştir. Ayrıca Alman hazine tahvili vadeli sözleşme getirilerinin yeni haberlere göre hızlı bir şekilde adapte olabildiği ve fiyatların Amerika Birleşik Devletleri makroekonomik haberlerine Avrupa Birliği'nin bütününü etkileyen veya ulusal haberlerinden ve İngiltere'den gelen haberlerden daha fazla tepki verdiği bilgileri yer almaktadır. Son olarak ise Almanya'nın hazine bonosu piyasalarına göre uluslararası finansal bağlarının uluslararası reel ekonomik ilişkileriyle aynı doğrultuda olmadığı ifade edilmiştir.

Chevallier (2009) çalışmasının sonuçlarında, karbon vadeli işlem sözleşme getirisi ile sadece ortak hisse senedi portföyü arasında istatistiksel olarak \% 1 önem seviyesinde anlaml ve negatif ilişki bulunduğu; diğer makroekonomik değişkenler olan T-Bill oranı, batık hisse getirisi ve piyasa portföyünün aşırı getirisi ile istatistiksel olarak anlamlı bir ilişki bulunamadığı belirtilmiştir. Enerji değişkenlerinden ise doğal gaz ve brent petrol değişkenlerinin karbon vadeli işlem sözleşmelerini istatistiksel olarak \% 1 önem seviyesinde ve pozitif olarak etkilediği; elektrik değişkenin ise istatistiksel olarak anlamlı bir etkiye sahip olmadı̆̆ 1 ifade edilmiştir.

Zügül ve Şahin (2009) çalışmasının sonuçlarında, hisse senedi getirileri ile M1 para arzı, döviz kuru ve faiz değişkenleri arasında negatif yönlü bir ilişki; enflasyon oranı ile ise pozitif yönlü bir ilişki bulunduğu ifade edilmiştir.

Batten vd. (2010) çalışmalarının sonuçlarında, altındaki oynaklığın parasal değişkenlerle açıklanabildiği fakat bu durumun gümüş için geçerli olmadığı ifade edilmiştir. Ayrıca değerli metaller arasında volatilite geribildirimi olduğuna dair kanıtların olmasına rağmen, genel olarak aynı makroekonomik faktörlerin dört değerli metal fiyat serisinin volatilite süreçlerini ortaklaşa olarak etkilediğine dair sınırlı kanıtların varlığg da çalışmanın sonuçları arasındadır.

Vrugt (2010) çalışmasının sonuçlarında, makroekonomik haberlerin tüm vadelerdeki hazine bonolarının getirilerini açıklamada ekonomik olarak önemli ve istatistikî olarak anlamlı olduğu yönünde bilgiler yer almaktadır.

Pen ve Sévi (2011) çalışmalarının sonuçlarında, petrol vadeli işlem sözleşme getirilerindeki değişkenliğin yaklaşık \%38'inin 4 faktörden oluşan basit bir kombinasyonla 
açıklanabileceği, ham petrol fiyatı üzerinde en büyük etkiye sahip olan faktörün, gelişmekte olan ülkelerden gelen gerçek (reel) makroekonomik değişkenlerle ilgili olduğu ifade edilmiştir.

Aktaş ve Akdağ (2013) çalışmalarının regresyon analizi sonuçlarında BİST-100 endeksi üzerinde mevduat faiz oranı, TÜFE, dolar kuru, kapasite kullanım oranı ve tüketici güven endeksinin etkili olduğu belirtilmiştir. Granger nedensellik testi sonuçlarında ise sadece kapasite kullanım oranı ile faiz oranının BİST-100 ile karşılıklı etkileşime sahip oldukları ifade edilmiştir.

Özgümüş vd (2013) çalışmalarının sonuçlarında, VOB'da işlem gören İMKB 100 vadeli işlem sözleşmesi getirilerinin S\&P 500 getirisinden pozitif, altın fiyatları ve enflasyondan ise negatif yönde; İMKB 100 vadeli işlem sözleşmesinin işlem hacminin, para arzından pozitif yönde, enflasyondan negatif yönde; İMKB 100 vadeli işlem sözleşme volatilitesinin altın fiyatları ile faiz oranından pozitif yönde, ithalattan ise negatif yönde etkilendiği belirtilmiştir. İMKB 30 vadeli işlem sözleşmelerinin getiri serilerinin S\&P 500'den pozitif yönde, altın ve CA/GSYİH' den negatif yönde; İMKB 30 vadeli işlem sözleşmesi işlem hacminin ihracattan pozitif yönde, enflasyondan negatif yönde; İMKB 30 vadeli işlem sözleşmesi volatilitesinin altın ve CA/GSYİH'den pozitif yönde, S\&P 500'den negatif yönde etkilendiği ifade edilmiştir. Dolar vadeli işlem sözleşmesinin getiri serilerinin altından pozitif yönde, S\&P 500'den negatif yönde; Dolar vadeli işlem sözleşmesinin işlem hacminin, CA/GSYİH ve altından pozitif yönde, Dolar vadeli işlem sözleşmesinin volatilitesinin ithalat ve S\&P 500'den negatif yönde etkilendiği gözlemlenmiştir. Euro vadeli işlem sözleşmesinin getirisinin, altından pozitif yönde, ekonomik büyümeden negatif yönde etkilendiği, Euro vadeli işlem sözleşmesinin işlem hacminin altından, S\&P 500'den ve para arzından pozitif yönde, Euro vadeli işlem sözleşmesinin volatilitesinin ise enflasyon ve altın fiyatlarından pozitif yönde, ithalattan negatif yönde etkilendiği bilgileri yer almaktadır.

Chia ve Lim (2015) çalışmalarının sonuçlarında, uzun dönemde hisse senedi fiyatlarının para arzı ve faiz oranlarından pozitif yönde; enflasyondan ise negatif yönde etkilendiğini ifade etmişlerdir. Sonuçlarda ayrıca parasal genişleme ve reel faiz oranlarından hisse senedi fiyatlarına doğru bir nedenselliğin olduğu da belirtilmiştir.

Çetin-Demir (2015) çalışmasının sonuçlarında, BIST 30 endeks vadeli işlem sözleşme fiyatını M2 para arzı ve S\&P 500 endeksinin pozitif yönde; risk priminin ise negatif yönde etkilediği belirtilmiştir.

Özdemir (2017) çalışmasının sonuçlarında, dolar vadeli işlem sözleşmesinden dolar kuruna, altın fiyatına, ihracat miktarına, ithalat miktarına ve sanayi üretim endeksine doğru bir nedensellik olduğunun tespit edildiği, dolar vadeli işlem sözleşmesi ile faiz oranı ve tüketici fiyat endeksi değişkenleri arasında herhangi bir nedensellik ilişkisi bulunamadığı belirtilmiştir.

Perçin (2019) çalışmasının sonuçlarında, hisse senedi piyasası volatilitesinin büyük ölçüde ulusal makroekonomik faktörlerden ziyade uluslararası makroekonomik faktörlerden etkilendiği; Türkiye gibi gelişmekte olan bir ülkenin sermaye piyasalarının uluslararası faktörlerin etkisine yoğun olarak maruz kaldığı ifade edilmiştir. 
Durmuş vd. (2019) çalışmalarının sonuçlarında, BİST Banka ile BİST Mali Endeks getirilerini en fazla altın fiyatlarının açıkladığı, ikinci sırada ise Euro kurunun olduğu belirtilmiştir. En az açıklayan makroekonomik değişkenin ise enflasyon oranı olduğu ifade edilmiş̧ir. Çalışmanın sonuçlarında ayrıca, enflasyon oranının endeks getirilerini en fazla negatif etkilediği, ikinci sırada ise mevduat faiz oranı, altın fiyatı ve Euro değişkenlerinin geldiği; en az negatif etkileyenin ise dolar olduğu bilgileri yer almaktadır.

Fattah ve Kocabıyık (2020) çalışmalarının sonuçlarında, Türkiye için para arzı ve döviz kuru ile BIST100 endeksi arasında çift yönlü nedensellik tespit edildiği, tüketici fiyat endeksinden BIST100'e ve BIST100'den ihracatın ithalatı karşılama oranı ile faiz oranına doğru tek yönlü nedensellik ilişkisi olduğu belirtilmiştir. Bununla beraber BIST100 ile sanayi üretim endeksi, petrol fiyatları ve altın fiyatı arasında herhangi bir nedensellik tespit edilmemiştir. ABD için ise araştırılan dönemde sadece para arzından S\&P500'e doğru tek yönlü nedensellik ilişkisine rastlanıldığı, S\&P500 endeksi ile tüketici fiyat endeksi, sanayi üretim endeksi, ihracatın ithalatı karşılama oranı, faiz oranı, petrol fiyatı ve altın fiyatı arasında herhangi bir nedenselliğe rastlanılmadığı ifade edilmiştir.

\section{3. ÇALIŞMANIN AMACI, KAPSAMI VE YÖNTEMI}

Çalışmada, Vadeli İşlem ve Opsiyon Piyasasında işlem gören VİOP 30 vadeli işlem sözleşmesinin getiri, işlem hacmi ve volatilitesini etkileyen makroekonomik faktörlerin ileriye ve geriye dönük adımsal regresyon analizi yardımıyla incelenmesi amaçlanmıştır. Çalışmanın analiz dönemi Ocak 2013-Aralık 2017 dönemi olarak belirlenmiştir. ${ }^{1}$

Adımsal regresyon analizinde, öncelikle bağımlı ve bağımsız değişken arasında korelasyon analizi yapılmakta, korelasyon ilişkisi yüksek ve istatistiksel olarak anlamlı olan değişkenler tek tek modele dahil edilerek model kurulmaya başlanmaktadır. $R^{2}$ ve $F$ istatistiğini yükselten değişkenlerle devam edilirken $\mathrm{R}^{2}$ ve $\mathrm{F}$ istatistiğini düşüren değişkenler modelden çıkarılmaktadır (Alpar,2003:345-346).

En Küçük Kareler (EKK) yöntemi kullanılarak oluşturulan modellerin geçerli tahmin verebilmesi için hata terimlerinin seri korelasyonlu olmaması, bağımsız değişkenler arasında ilişkinin olmaması, hata terimlerinin normal dağılıma sahip olması ve hata terimlerinin sabit varyanslı olması gibi koşulları sağlaması gerekmektedir (Tarı,2012:22-27). Çalışmada kurulan EKK ile ilgili tüm modellerde, hata terimlerinin seri korelasyonlu olup olmadığını test etmek için Breusch-Godfrey Lagrange Multiplier (BGLM) testi, bağımsız değişkenler arasındaki ilişkiyi test etmek için Variance Inflation Factors (VIF) testi, hata terimlerinin sabit varyanslı olup olmadığını test etmek için White ve Autoregressive Conditional Heteroskedasticity (ARCH) testi, normallik testi için Jaqua-Bera test istatistiği ve yapısal kırılma için Cumulative Sum of the Recursive Residuals ${ }^{2}$ (CUSUM) ve CUSUM of Squares

\footnotetext{
${ }^{1}$ Çalışmaya başlanırken pay vadeli işlem sözleşmeleri de analize dahil edilmiş ve bu sözleşmelerin 21 Aralık 2012 itibariyle işlem görmeye başlamış olması nedeniyle analizin başlangıç tarihi 2013 yılı olarak belirlenmiştir. Fakat yapılan analiz sonuçlarında anlamlı sonuçlar elde edilmediği için pay vadeli işlem sözleşmelerine çalışmada yer verilmemiştir.

2 CUSUM test, ardışı hatalar ile hesaplanmakta iken CUSUM of Squares ardışık hata kareleri ile hesaplanmaktadır ve her iki test de veri setinde kırılmanın olup olmadığı konusunda kabaca bilgi vermektedir. Belli bir güven aralığında modelin hatalarının grafiği çizilerek güven sınırları tespit edilir. Güven sınırları dışına çıkıldığında yapısal değişiklik olduğuna, çıkılmadığında ise yapısal değişiklik olmadığına karar verilmektedir.
} 
testleri kullanılmıştır. Çalışmada EKK varsayımlarının incelendiği sayılan testlerden VIF, CUSUM ve CUSUM of Squares testleri haricindeki testler sonuç tablolarında yer alırken bu testler yer tasarrufu açısından tablolara eklenmemiştir.

Çalışmada incelenen değişkenlerin zaman serisi olmaları dolayısıyla öncelikle durağan olup olmadıkları incelenmiştir. Durağanlık analizi literatürde yaygın olarak kullanılan Augmented Dickey-Fuller (ADF), Phillips-Perron (PP) ve Kwaitkowski, Phillips, Schmidt ve Shin (KPSS) testleri kullanılarak gerçekleştirilmiştir. ADF, PP ve KPSS testlerinden herhangi ikisinde durağan olan veri seti durağan olarak kabul edilmiş, en az iki testte durağan olmayan seriler birinci farkları alınarak durağan hale getirilmiştir. ${ }^{3}$ Sonrasında ise VIOP 30 vadeli işlem sözleşmesinin getirisine, işlem hacmine ve volatilitesine etki eden makroekonomik faktörler aşağıdaki regresyon modelleri ile incelenmiştir.

$$
R_{\mathrm{V}, \mathrm{t}}=\alpha_{0}+\alpha_{\mathrm{k}} \mathrm{X}_{\mathrm{k}, \mathrm{t}}+\varepsilon_{\tau}
$$

$\mathrm{R}_{\mathrm{v}, \mathrm{t}}$; aylık bazda VIOP30 vadeli işlem sözleşme getirisini, $\mathrm{X}_{\mathrm{k}, \mathrm{t}}$ ise VİOP 30 vadeli işlem sözleşme getirisini etkileyeceği düşünülen bağımsız değişken matrisini ifade etmektedir.

$$
\dot{I} H_{\mathrm{v}, \mathrm{t}}=\beta_{0}+\beta_{\mathrm{k}} \mathrm{X}_{\mathrm{k}, \mathrm{t}}+\varepsilon_{\tau}
$$

$\dot{\mathrm{I}} \mathrm{H}_{\mathrm{v}, \mathrm{t}}$; aylık bazda VİOP 30 vadeli işlem sözleşmesi işlem hacmini, $\mathrm{X}_{\mathrm{k}, \mathrm{t}}$ ise vadeli işlem sözleşme işlem hacmini etkileyeceği düşünülen bağımsız değişken matrisini ifade etmektedir

$$
\mathrm{V}_{\mathrm{v}, \mathrm{t}}=\beta_{0}+\beta_{\mathrm{k}} \mathrm{X}_{\mathrm{k}, \mathrm{t}}+\varepsilon_{\tau}
$$

$\mathrm{V}_{\mathrm{v}, \mathrm{t}}$; aylık bazda VİOP 30 vadeli işlem sözleşme volatilitesini, $\mathrm{X}_{\mathrm{k}, \mathrm{t}}$ ise vadeli işlem sözleşme volatilitesini etkileyeceği düşünülen bağımsız değişken matrisini ifade etmektedir.

Çalışmada volatilitesi incelenen VİOP 30 vadeli işlem sözleşmesi için aylık getiri serisi oluşturulmuş fakat aylık getiri serisinde koşullu değişen varyans özelliği bulgulanamamış ve bu sebeple GARCH tipi modeller tahmin edilememiştir. Bollerslev (1986) tarafından geliştirilen GARCH modeli, $\mathrm{t}$ dönemindeki koşullu varyansın (ht) sadece hata terimlerinin geçmiş değerlerinin karesine bağlı değil aynı zamanda geçmişteki koşullu varyansına da bağlı olduğunu ifade etmektedir. GARCH modelinin geçerli olabilmesi için tahmin edilen koşullu varyans denkleminin ARCH ve GARCH parametrelerinin sıfıra eşit ya da sıfırdan büyük olması ( $\alpha i \geq 0 ; \beta j \geq 0, i=1,2,3 . . q)$ ve koşullu varyans denkleminin sağındaki sabit katsayının sıfırdan büyük $(\omega>0)$ olması gerekmektedir. Ayrıca durağanlığın sağlanabilmesi için de koşullu varyans denkleminin sağında bulunan sabit terim haricindeki bütün parametrelerin toplamının birden küçük olması gerekmektedir. Aylık getiri serisinde koşullu değişen varyans özelliği bulgulanamadığ için çalışmada öncelikle günlük getiri serileri kullanılarak günlük getiri volatilite serileri hesaplanmıştır. Sonrasında ise Liu ve Tse, (2013) çalışmasından yararlanılarak günlük getiri volatilite serileri toplanarak aylık frekansa dönüştürülmüştür.

\footnotetext{
${ }^{3}$ Durağanlık tablosu Ek-1'de yer almaktadır.
} 
İncelenen VİOP30 vadeli işlem sözleşmesine ilişkin volatilite değerleri hesaplanırken Generalized Autoregressive Conditional Heteroskedasticity $(\mathrm{GARCH})(1,1)$, GARCH in Mean (GARCH-M)(1,1), Exponential GARCH (EGARCH)(1,1) ve Threshold GARCH (TGARCH) $(1,1)$ modelleri denenmiştir. EGARCH(1,1) ve TGARCH(1,1) modellerinde ARCH etkisinin ortadan kalkmamas1, GARCH-M(1,1) modelinde ise GARCH parametresinin anlamsiz çıkması nedeniyle en iyi performans sergileyen model $\operatorname{GARCH}(1,1)$ modeli olmuştur. $\mathrm{Bu}$ sebeple VIOP30 vadeli işlem sözleşmesi volatilite değerleri hesaplanırken $\operatorname{GARCH}(1,1)$ modeli kullanılmıştır.

\section{VERİ SETİ VE ANALIZ SONUÇLARI}

Çalışmanın veri seti Ocak 2013- Aralık 2017 döneminde VİOP' ta işlem gören VİOP 30 vadeli işlem sözleşmesine ait aylık bazda getiri, işlem hacmi ve volatilite ile bazı makroekonomik değişkenlerden oluşmaktadır. VIOP 30 endeksi, Borsa İstanbul Pay (hisse) Piyasası'nda işlem gören en yüksek hacimli ilk 30 hisseden oluşan BİST 30 endeksinin dayanak varlık olduğu sözleşmedir.

Tablo 2. Adımsal Regresyon Analizinde Kullanılan Bağımlı Değişkenler

\begin{tabular}{ll}
\hline Rviop30 & :BİST 30 endeks vadeli işlem sözleşmesi aylık bazda getiri \\
\hline İHviop3 & :BİST 30 endeks vadeli işlem sözleşmesi aylık bazda işlem hacmi \\
\hline Vviop30 & :BİST 30 endeks vadeli işlem sözleşmesi aylık bazda volatilite \\
\hline
\end{tabular}

Vade tarihine en yakın vadeli işlem sözleşmeleri en çok işlem gören ve likiditeye en çok sahip olan sözleşme türleri olduğundan dolayı daha çok tercih edilirler (Andersson vd. 2006;13). Bu sebeple çalışmada kullanılacak bağımlı değişkenler için sözleşme seçimi yapılırken en yakın vadedeki sözleşme seçilmiştir. Çalışmada incelenen getiri serileri $R_{\mathrm{v}, \mathrm{t}}=$ $100 \mathrm{x} \ln \left(\mathrm{P}_{\mathrm{t}} / \mathrm{P}_{\mathrm{t}-1}\right)$ formülü kullanılarak hesaplanmıştır. Benzer işlem, işlem hacmi ve volatilite serileri için de uygulanarak bu değişkenlere ilişkin değişim serileri elde edilmiştir $\left(\dot{\mathrm{I}}_{\mathrm{v}, \mathrm{t}}=\mathrm{ln}\right.$ $\left(\dot{\mathrm{IH}}_{\mathrm{t}} / \dot{\mathrm{I}}_{\mathrm{t}-1}\right)$ ve $\left(\mathrm{V}_{\mathrm{v}, \mathrm{t}}=\ln \left(\mathrm{V}_{\mathrm{t}} / \mathrm{V}_{\mathrm{t}-1}\right)\right)$. Çalışmada yer alan makroekonomik değişkenler Tablo 3'te belirtilmiştir.

Tablo 3. Adımsal Regresyon Analizinde Kullanılan Makroekonomik Değişkenler

\begin{tabular}{|c|c|}
\hline BA/GSYİHt & Bütçe açığının GSYİH'ye oranı \\
\hline SÜEt & Sanayi üretim endeksi $(2015=100)$ \\
\hline CA/GSYIHH & Cari işlemler açığının GSYİH'ye oranı \\
\hline TÜFE $_{t}$ & Tüketici Fiyat Endeksi (2003=100) \\
\hline$\Delta$ Faizt & TCMB gecelik faiz oranı \\
\hline Altınt & Külçe altın fiyatları \\
\hline Lİhracat & Aylık bazda toplam ihracat $(2010=100)$ \\
\hline$\Delta$ Lİthalat ${ }_{t}$ & Aylık bazda toplam ithalat $(2010=100)$ \\
\hline$\Delta$ LParaarzlt & M2 para arz1 \\
\hline Petrol $_{t}$ & Brent petrol fiyatları \\
\hline VIX $_{t}$ & Volatilite Endeksi \\
\hline
\end{tabular}

Not: "L" işareti değişkenin doğal logaritmasının alındığını ifade etmektedir.

Tablo 3'deki değişkenlerden sanayi üretim endeksi, tüketici fiyat endeksi değişkenlerinin aylık değişim oranları; altın, petrol ve VIX endeksi değişkenlerinin ise getiri serileri; ihracat, ithalat ve para arzının ise doğal logaritmaları alınarak analizde bu şekilde kullanılmıştır. BA/GSYİH, CA/GSYİH ve faiz değişkenlerinde ise herhangi bir işlem 
yapılmadan bu şekilde kullanılmıştır. Veri setinde durağan halde olan değişkenler durağan formatlarıyla, durağan olmayanlar ise durağan hale getirildikten sonraki formatlarıyla kullanılmıştır. ${ }^{4}$

Çalışmada kullanılan VİOP sözleşmelerine ait veriler datastore.borsaistanbul.com adresinden, VIX endeksine ilişkin veriler "www.tr.investing.com" adresinden, makroekonomik değişkenlere ait veriler ise "www.tuik.gov.tr" ve "www.tcmb.gov.tr" adreslerinden temin edilmiştir. Analiz "Eviews 10" programı kullanılarak gerçekleştirilmiştir.

Çalışmadaki değişkenler incelendiğinde GSYİH değişkeni haricindekilerin aylık frekansta olduğu görülmektedir. Veriler arasında analizin gerçekleştirilebilmesi için aynı frekansta olmaları gerektiğinden dolayı GSYİH değişkeni de daha önce de literatürde kullanılmış olan kübik spline yöntemi yardımıyla aylık frekansa dönüştürülmüştür.

\subsection{VİOP 30 Sözleşme Getirisine Etki Eden Makroekonomik Faktörler}

VİOP 30 vadeli işlem sözleşme getirilerine etki eden makroekonomik faktörlere ilişkin sonuçlar aşağıdaki tabloda yer almaktadır.

Tablo 4. VİOP 30 Getiri Serisi ve Makroekonomik Değişkenler Korelasyon Analizi

\begin{tabular}{cccccc}
\hline $\begin{array}{c}\text { Makroekonomik } \\
\text { Değişkenler }\end{array}$ & $\begin{array}{c}\text { VİOP30 } \\
\text { Getiri }\end{array}$ & Prob & $\begin{array}{c}\text { Makroekonomik } \\
\text { Değişkenler }\end{array}$ & $\begin{array}{c}\text { VİOP30 } \\
\text { Getiri }\end{array}$ & Prob \\
\hline BA/GSYİH & 0.0345 & 0.7950 & Lİthalat & 0.1574 & 0.2337 \\
\hline SÜE & 0.1006 & 0.4480 & $\Delta($ LParaarzi) & -0.3566 & 0.0056 \\
\hline CA/GSYİH & 0.1262 & 0.3406 & TÜFE & 0.2634 & 0.0438 \\
\hline Faiz & -0.1585 & 0.2305 & Petrol & 0.0058 & 0.9647 \\
\hline Altın & -0.0455 & 0.7318 & VIX Endeksi & -0.2841 & 0.0292 \\
\hline Lİhracat & 0.2587 & 0.0479 & & &
\end{tabular}

Tablodaki korelasyon analiz sonuçlarına bakıldığında VIOP 30 vadeli işlem sözleşme getirisi ile BA/GSYİH, SÜE, CA/GSYİH, Lithalat, Lihracat, TÜFE, petrol değişkenleri arasında pozitif; faiz, altın, para arzı ve VIX endeksi değişkenleriyle ise negatif korelasyon ilişkisi olduğu görülmektedir. Literatürde değişkenler arasındaki ilişkileri destekleyecek bulgular mevcuttur; bütçe açığı, faiz, altın, sanayi üretim endeksi ve ithalat değişkenleri ile hisse senedi getirileri arasındaki ilişkilerin yönü ve açıklamaları için Albeni ve Demir (2005), Brigham (2006), Cihangir ve Kandemir (2010), Kırbaş-Kasman (2006), Coşkun vd. (2016) incelenebilir. Korelasyon analizinde söz konusu değişkenlerin matematiksel anlamlılıkları literatür ile uyumlu olsa da istatistiksel anlamlılıkları sağlanamadığı için analiz dışı bırakılmıştır. Buna karşın İhracat, para arzı, TÜFE ve VIX endeksi değişkenleri \%5 düzeyinde anlamlıdır, analize bu açıklayıcı değişkenler ile devam edilmiştir.

\footnotetext{
${ }^{4}$ Durağanlık analiz sonuçları EK 1'de yer almaktadır.
} 
Tablo 5. VİOP 30 Getiri Serisine Etki Eden Makroekonomik Değişkenler Adımsal Regresyon Sonucu

\begin{tabular}{|c|c|c|c|c|c|}
\hline \multicolumn{6}{|c|}{ Bağımlı Değiş̧ken: RViop30,t } \\
\hline A(LParaarz & & -4.2016 & 1.4020 & -2.9967 & 0.0041 \\
\hline Vix Endeks & & -0.0778 & 0.0454 & -1.7121 & 0.0926 \\
\hline$T \ddot{U F E} E_{t}$ & & 0.0196 & 0.0103 & 1.8979 & 0.0630 \\
\hline Líhracat $_{t}$ & & 0.4273 & 0.1879 & 2.2736 & 0.0270 \\
\hline C & & -4.2993 & 1.8975 & -2.2656 & 0.0275 \\
\hline Düz- $\mathbf{R}^{2}$ & \multicolumn{2}{|l|}{0.2519} & F-ist & :5.8839 [0.0005] & \\
\hline B-G:F-ist & \multicolumn{2}{|c|}{$: 0.5112[0.4746]$} & W:F-ist & :6.8794 [0.9083) & \\
\hline J-B:F-ist & \multicolumn{2}{|c|}{ : 1.6130 [0.4464] } & ARCH:F-ist & $: 0.7702[0.3801]$ & \\
\hline
\end{tabular}

Tablo 5 incelendiğinde VİOP 30 vadeli işlem sözleşme getirisine etki eden faktörlerin istatistiksel olarak \%1 önem seviyesinde para arzı, \% 5 önem seviyesinde ihracat, \% 10 önem seviyesinde ise VIX endeksi ile TÜFE değişkenlerinin anlamlı olduğu görülmektedir. Para arzı ve VIX endeksindeki artışlar VIOP 30 getirisini negatif yönde etkilerken; TÜFE ve ihracat değişkenleri pozitif yönde etkilemektedir. Söz konusu bu değişkenlerin VİOP3 0 vadeli işlem sözleşme getirisindeki değişimlerin yaklaşık \%25,2 sini açıklama yeteneğine sahip olduğu görülmektedir. Model parametrelerinin geçerliliği için gerekli olan varsayımlar incelenmiş ve \% 5 önem seviyesinde geçerli sonuçlar verdiği tespit edilmiştir. Analiz sonuçları değerlendirildiğinde para arzı parametre tahmininin Zügül ve Şahin (2009), enflasyon parametre tahminin Al-Khazali (2003) çalışmalarıyla benzerlik gösterdiği bulgulanmıştır.

\subsection{VİOP 30 Sözleșmesi İșlem Hacmine Etki Eden Makroekonomik Faktörler}

VİOP 30 vadeli işlem sözleşmesi işlem hacmine etki eden makroekonomik faktörlere ilişkin sonuçlar aşağıdaki tabloda yer almaktadır.

Tablo 6. VİOP 30 İşlem Hacmi ve Makroekonomik Değişkenler Korelasyon Analizi

\begin{tabular}{cccccc}
\hline $\begin{array}{c}\text { Makroekonomik } \\
\text { Değişkenler }\end{array}$ & $\begin{array}{c}\text { VİOP 30 } \\
\text { Isslem Hacmi }\end{array}$ & Prob & $\begin{array}{c}\text { Makroekonomik } \\
\text { Değişkenler }\end{array}$ & $\begin{array}{c}\text { VİOP 30 } \\
\text { İşlem Hacmi }\end{array}$ & Prob \\
\hline BA/GSYİH & 0.4542 & 0.0003 & L்̇thalat & -0.0969 & 0.4649 \\
\hline SÜE & 0.0712 & 0.5919 & $\Delta$ (LParaarzı) & -0.0022 & 0.9862 \\
\hline CA/GSYİH & 0.0175 & 0.8952 & TÜFE & 0.2230 & 0.0896 \\
\hline Faiz & 0.0449 & 0.7353 & Petrol & -0.1549 & 0.2412 \\
\hline Altın & 0.1636 & 0.2155 & VIX Endeksi & -0.1268 & 0.3383 \\
\hline Lİhracat & -0.0405 & 0.7605 & & & \\
\hline
\end{tabular}

Korelasyon tablosu incelendiğinde, VİOP 30 vadeli işlem sözleşmesi işlem hacminin BA/GSYİH, SÜE, CA/GSYİH, faiz, altın ve TÜFE değişkenleriyle pozitif; Lihracat, Lithalat, Lparaarzı, petrol ve VIX Endeksi değişkenleriyle ise negatif korelasyona sahip olduğu görülmektedir. VİOP30 işlem hacmi ile Sanayi üretim endeksi (Kırbaş-Kasman 2006), petrol 
fiyatları (Basher ve Sardosky, 2006) ve TÜFE değişkenleri arasında hesaplanan katsayıların yönü literatür ile paralellik göstermektedir. Ancak BA/GSYİH ve TÜFE değişkenleri haricindekilerin istatistiksel anlamlılı̆̆ sağlanamamıştır. Dolayısıyla adımsal regresyon analizinde işlem hacmine etki etmesi beklenen makroekonomik değişkenlerden sadece ikisi; BA/GSYİH ve TÜFE değişkenleri ile analize devam edilmiştir.

Tablo 7. VİOP 30 Vadeli İşlem Sözleşmesi İşlem Hacmine Etki Eden Makroekonomik Değişkenler Adımsal Regresyon Sonucu

\begin{tabular}{|c|c|c|c|c|c|}
\hline \multicolumn{6}{|c|}{ Bağımlı Değişken:İHVioP30,t } \\
\hline \multicolumn{2}{|c|}{ Bağımsız Değişkenler } & Katsayilar & Std. Hata & t-ist & p-değeri. \\
\hline \multicolumn{2}{|c|}{ BA/GSYİH } & 5.1895 & 1.5843 & 3.2754 & 0.0018 \\
\hline \multicolumn{2}{|l|}{$\dot{I} H_{\text {VIOP30,t-1 }}$} & -0.3462 & 0.1171 & -2.9558 & 0.0046 \\
\hline \multicolumn{2}{|l|}{ C } & 0.0292 & 0.0203 & 1.4375 & 0.1561 \\
\hline \multicolumn{3}{|c|}{ Düz- $\mathbf{R}^{2} \quad: 0.2889$} & F-ist & $: 12.7830[0.0000]$ & \\
\hline B-G:F-ist & \multicolumn{2}{|c|}{$: 1.2079$ [0.2717] } & W:F-ist & $: 1.2349$ [0.5393] & \\
\hline J-B:F-ist & \multicolumn{2}{|c|}{ :2. 8679 [0.2383] } & ARCH:F-ist & $: 2.4176[0.1200]$ & \\
\hline
\end{tabular}

Adımsal regresyon analizinde TÜFE değişkeninin de istatistiksel anlamlılığının sağlanamadığı görülmüştür ve bu sebeple sonuç tablosunda yer almamıştır. Modelin geçerliliği ile ilgili varsayımlar incelendiğinde hata terimleri arasında seri korelasyon varlığ dışında herhangi bir soruna rastlanılmamıştır. Bu sorunu gidermek için ise modele bağımlı değişkenin bir gecikmeli değeri eklenmiştir. Analizde hem matematiksel işaret hem de istatistiksel açıdan anlamlı tek faktörün BA/GSYİH değişkeni olduğu bulgulanmıştır.

\subsection{VİOP 30 Sözleșme Volatilitesine Etki Eden Makroekonomik Faktörler}

VİOP30 vadeli işlem sözleşmesine ilişkin volatilite değeri hesaplamada kullanılan GARCH(1,1), GARCH-M(1,1), EGARCH(1,1) VE TGARCH(1,1) modellerine ilişkin sonuçlar aşağıdaki tabloda yer almaktadır.

Tablo 8. GARCH(1,1), GARCH-M(1,1), EGARCH(1,1) ve TGARCH(1,1) Model Sonuçları

\begin{tabular}{|c|c|c|c|c|}
\hline & GARCH(1,1) & GARCH M(1,1) & EGARCH(1,1) & TGARCH $(1,1)$ \\
\hline \multicolumn{5}{|l|}{ Ortalama Denklemi } \\
\hline GARCH & - & -7.0365 & - & - \\
\hline Sabit Terim & 0.0006 & $0.0020^{*}$ & $0.0005^{*}$ & $0.0006^{* *}$ \\
\hline AR(1) & $0.8547^{* * *}$ & $0.8542^{* * *}$ & -0.0381 & -0.0367 \\
\hline AR(2) & $-0.9728^{* * *}$ & $-0.9730^{* * *}$ & $0.8001^{* * *}$ & $0.7993^{* * *}$ \\
\hline MA(1) & $-0.8698^{* * *}$ & $-0.8694^{* * *}$ & 0.0036 & 0.0029 \\
\hline MA(2) & $0.9943^{* * *}$ & $0.9941^{* * *}$ & $-0.7864^{* * *}$ & $-0.7904^{* * *}$ \\
\hline \multicolumn{5}{|l|}{ Varyans Denklemi } \\
\hline Sabit Terim & $4.64 \mathrm{E}-06^{* * *}$ & $4.52 \mathrm{E}-06^{* * *}$ & $-0.2745^{* * *}$ & $3.70 \mathrm{E}-06^{* * *}$ \\
\hline$\alpha 1$ & $0.0364^{* * *}$ & $0.0364^{* * *}$ & $0.0873^{* * *}$ & 0.0042 \\
\hline$\beta 1$ & $0.9433^{* * *}$ & $0.9438^{* * *}$ & $0.9750^{* * *}$ & $0.9567^{* * *}$ \\
\hline$\gamma$ & - & - & $-0.0549^{* * *}$ & $0.0442^{* * *}$ \\
\hline T-Dist. Dof & - & - & $4.7151^{* * *}$ & $4.6458^{* * *}$ \\
\hline Log-likelihood & 3506.189 & 3507.090 & 3570.476 & 3571.562 \\
\hline AIC & -5.5971 & -5.5969 & -5.6967 & -5.6984 \\
\hline SIC & -5.5642 & -5.5600 & -5.6557 & -5.6574 \\
\hline ARCH LM T *(R2) & 8.4016 & 7.7167 & 11.3103 & 7.7854 \\
\hline $\mathbf{P}$ & 0.1354 & 0.1726 & 0.0456 & 0.0507 \\
\hline
\end{tabular}


Tablo 8 incelendiğinde EGARCH ve TGARCH modellerinde ARCH etkisinin ortadan kalkmadığı ve GARCH-M modelinde ise GARCH parametresinin anlamsız çıktığı görülmektedir. Dolayısıyla bu üç model kullanılamamıştır. GARCH modeline ilişkin sonuçta ise $\alpha$ ve $\beta$ parametreleri \% 1 önem düzeyinde anlamlı çıkmış, bununla birlikte GARCH modeli için gerekli olan $\alpha+\beta<1$ olma şartı da sağlanmıştır.

Uygun $\operatorname{GARCH}(1,1)$ tipi model sonucunda hesaplanan volatilite değerleri aylık frekansa dönüştürülmüş ve regresyon analizi bu şekilde uygulanmıştır. Aşağıdaki tabloda VİOP30 vadeli işlem sözleşme volatilitesine etki eden makroekonomik faktörlere ilişkin sonuçlar yer almaktadır.

Tablo 9. VİOP 30 Volatilite ve Makroekonomik Değişkenler Korelasyon Analizi

\begin{tabular}{llllll}
\hline $\begin{array}{l}\text { Makroekonomik } \\
\text { Değişkenler }\end{array}$ & $\begin{array}{l}\text { VİOP30 } \\
\text { Volatilite }\end{array}$ & Prob & $\begin{array}{l}\text { Makroekonomik } \\
\text { Değişkenler }\end{array}$ & $\begin{array}{l}\text { VIOP30 } \\
\text { Volatilite }\end{array}$ & Prob \\
\hline BA/GSYİH & 0.0026 & 0.9843 & Lİthalat & -0.0577 & 0.6640 \\
\hline SÜE & 0.0329 & 0.8041 & $\Delta$ (LParaarzı) & 0.1169 & 0.3778 \\
\hline CA/GSYİH & -0.3625 & 0.0048 & TÜFE & -0.0190 & 0.8862 \\
\hline Faiz & 0.3663 & 0.0043 & Petrol & -0.0187 & 0.8881 \\
\hline Altın & -0.0445 & 0.7378 & VIX Endeksi & 0.0553 & 0.6851 \\
\hline Lİhracat & -0.0074 & 0.9552 & & & \\
\hline
\end{tabular}

VİOP 30 vadeli işlem sözleşme volatilitesi ile BA/GSYİH, SÜE, Faiz, Lparaarzı ve VIX endeksi değişkenleri arasında pozitif; CA/GSYİH, altın, Lihracat, Lithalat, TÜFE ve petrol değişkenleriyle ise negatif bir ilişki mevcuttur. Ancak CA/GSYİH ile faiz değişkeni haricindekilerin istatistiksel olarak anlamlılığı sağlanamamıştır.

Tablo 10. VİOP 30 Vadeli İşlem Sözleşme Volatilitesine Etki Eden Makroekonomik Adımsal Regresyon Sonucu

\begin{tabular}{|c|c|c|c|c|c|}
\hline \multicolumn{6}{|c|}{ Bağımlı Değişken:VViop30,t } \\
\hline \multicolumn{2}{|c|}{ Bağımsız Değişkenler } & Katsayılar & Std. Hata & t-ist & p-değeri \\
\hline \multicolumn{2}{|l|}{$\Delta($ Faizt $)$} & 0.0006 & 0.0003 & 2.0310 & 0.0471 \\
\hline \multicolumn{2}{|l|}{ CA/GSYİH } & -0.1424 & 0.0523 & -2.7240 & 0.0086 \\
\hline \multicolumn{2}{|l|}{ Vviop30,t-1 } & 0.5161 & 0.1014 & 5.0900 & 0.0000 \\
\hline \multicolumn{2}{|l|}{ C } & 0.0014 & 0.0005 & 2.4537 & 0.0173 \\
\hline Düz- $\mathbf{R}^{2}$ & \multicolumn{2}{|c|}{$: 0.4691$} & F-ist & :18.0841[0.0000] & \\
\hline B-G:F-ist & \multicolumn{2}{|c|}{ :0.0125 [0.9107] } & W:F-ist & :3.6060 [0.9354] & \\
\hline J-B:F-ist & \multicolumn{2}{|c|}{ :125.8121 [0.0000] } & ARCH:F-ist & : $0.6346[0.7281]$ & \\
\hline
\end{tabular}

VİOP 30 vadeli işlem sözleşmesinin volatilitesine etki eden faktörler istatistiksel olarak \%1 önem seviyesinde cari açığın GSYIH'ye oranı ve \% 5 önem seviyesinde faiz olarak bulgulanmıştır. Cari açığın GSYİH'ye oranındaki artışlar VİOP 30 vadeli işlem sözleşmesinin volatilitesini azaltırken, faiz oranında meydana gelen artışlar VİOP 30 vadeli işlem sözleşmesinin volatilitesini artırmaktadır. Faiz parametre tahminin Özgümüş vd. (2013) ile uyumlu çıktığı saptanmıştır. EKK varsayımları test edilmiş hata terimleri arasında seri korelasyon varlığı ve normallik sorunu dışında herhangi bir problemle karşılaşılmamıştır. 
Hata terimleri arasındaki seri korelasyon varlığını gidermek için modele bağımlı değişkenin bir gecikmeli değeri dahil edilerek problem giderilmiştir.

\section{SONUÇ VE ÖNERILER}

Piyasalarda küreleşmenin de etkisiyle finansal ya da finansal olmayan nitelikteki risklerle karşılaşılması, vadeli işlem piyasalarının da riskleri minimize etme imkânı sağlaması, yatırımcıların bu piyasalara yönelmesine neden olmuştur. Yatırımcılar bu piyasalarda hedging, spekülasyon ve arbitraj seçeneklerinden herhangi birini tercih ederek işlemlerini gerçekleştirebilmektedir. Dolayısıyla gerek hedging gerekse spekülasyon ve arbitraj seçenekleri için işlem gerçekleştirecek yatırımcılar açısından işlem yapacakları sözleşmenin getirisini, işlem hacmini ve volatilitesini etkileyen faktörlerin incelenmesi büyük önem taşımaktadır. Çalışmada, Vadeli İşlem ve Opsiyon Piyasasında işlem gören VİOP 30 vadeli işlem sözleşme getirisi, işlem hacmi ve volatilitesine etki eden makroekonomik faktörler incelenmiştir.

Çalışmanın sonuçlarında, VİOP 30 vadeli işlem sözleşme getirisinin enflasyon ve ihracat değişkenlerinden pozitif yönde, VIX endeksi ve para arzından ise negatif yönde etkilendiği bulgulanmıştır. Literatürde enflasyon ile hisse senedi getirileri arasındaki ilişki konusunda tam bir görüş birliği mevcut değildir. Enflasyonun hisse senedi fiyatlarını negatif yönde etkilediğini belirtenlerin yanı sıra pozitif olarak etkilediğini belirtenler de olmuştur. AlKhazali (2003:310) çalışmasındaki uzun dönem bulguları, beklenen enflasyon ve beklenen enflasyondaki artışla hisse senedi fiyatları arasında hisse senetlerinin enflasyondan korunma aracı olarak algılanmasından kaynaklanan pozitif yönde bir ilişki içeren Fisher etkisini destekler niteliktedir. Çalışmadan elde edilen sonuç bu açıdan söz konusu ifadeyle aynı doğrultuda çıkmıştır. Diğer bir ifadeyle hisse senetlerinin enflasyondan korunma aracı olarak algılanmasından dolayı VIOP 30 getirileri ile enflasyon arasında pozitif ilişki çıktığı düşünülmektedir. Aktaş ve Akdağ $(2013 ; 56)$ çalışmalarında ihracatın sanayileşmiş ve sanayileşmekte olan ülkelerin ekonomik gelişmişlik göstergelerinden biri olarak değerlendirilebileceğini ve ihracat fazlasına sahip bir ekonominin sağlıklı bir ekonomik sistemin göstergesi olduğunu ifade etmişlerdir. Bu açıdan değerlendirildiğinde ihracatın fazla olmasının yatırımcılar açısından olumlu değerlendirileceği ve bu durumun da hisse senedi fiyatlarına olumlu yansımasından dolayı pozitif ilişki elde edildiği düşünülmektedir. VIX endeksinin yükselmesi (\%30'dan fazla olması) yatırımcıların risk algısının yükseldiğini ve geleceğe yönelik beklentilerinin kötüleştiğini ifade ederken; VIX endeksinin azalması (\%20'den az olması) yatırımcıların risk algısının azaldığını ve geleceğe daha iyimser baktıklarını ifade etmektedir. Dolayısıyla VIX endeksi ile hisse senedi getirileri arasındaki ilişkinin negatif çıkmasının bu durumdan kaynaklanabileceği düşünülmektedir.

VIOP 30 vadeli işlem sözleșmesi işlem hacminin BA/GSYİH değişkeninden pozitif yönde etkilendiği sonucuna ulaşılmıştır. Albeni ve Demir'e (2005:5) göre kamu harcamalarının artması çoğaltan etkisi aracılığıyla gelir artışını ekonominin tamamına yayarak hisse senedi fiyatlarının yükselmesine neden olmaktadır. Buradan hareketle hisse senedi fiyatlarının artmasının yatırımcılar için cazip hale geleceği ve bu durumun da VİOP30 vadeli işlem sözleşmesi işlem hacmini artıracağı düşünülmektedir.

VİOP 30 vadeli işlem sözleşme volatilitesinin ise faizden pozitif, CA/GSYİH değişkeninden negatif yönde etkilendiği sonucuna ulaşılmıştır. Alternatif bir yatırım aracı 
olması nedeniyle faiz oranlarının artmasının hisse senedi fiyatı üzerinde yaratacağı olumsuz etkiden dolayı piyasada sert ve ani çıkışların meydana gelebileceği ve bu durumun da volatiliteyi artırabileceği düşünülmektedir.

Çalışma sonuçları literatür ile karşılaştırıldığında, bazı çalışmalar ile benzerlik (Zügül ve Şahin, 2009; Chia ve Lim, 2015) gösterdiği saptanmıştır. Genelde para arzındaki artışların hisse senedi piyasasını dolayısıyla borsa endeksini yükselttiği yönündeki sonuçlara ulaşıldığı görülmektedir. Bununla birlikte Zügül ve Şahin (2009) çalışmalarında para arzı ile hisse senetleri fiyatları arasında negatif ilişki bulgulamışlardır. Çalışmamızın sonucu bu açıdan söz konusu çalışmayla benzerlik göstermektedir.

Çalışma sonuçlarının bazı çalışmalar ile de farklılık gösterdiği (Çetin- Demir, 2015) tespit edilmiştir. Bununla beraber Özgümüş vd. (2013) çalışması ile bazı sonuçlar açısından benzerlik gösterdiği bazı sonuçlar açısından ise farklılık gösterdiği saptanmıştır. Bu durumun vadeli işlem sözleşmesi, incelenen piyasa ve incelenen zamanların farklı olmasından kaynaklandığı düşünülmektedir. Özellikle 2012 y1lı öncesi dönem değerlendirildiğinde vadeli işlem sözleşmelerine ilişkin işlem hacimlerinin çalışmada incelenen döneme göre daha düşük olduğu görülmektedir. 2012 yılı sonrasında vadeli işlem sözleşmelerindeki derinlik ve çeşitlilik artmıştır. Bununla birlikte 2008 yılında yaşanan finansal ve ekonomik krizden uluslararası sermaye akımları ve makroekonomik göstergeler olumsuz etkilenmiş ve bu etki sonraki birkaç yıl da devam etmiştir. Dolayısıyla yapılan çalışma ile diğer çalışmalar arasındaki farklılığın sayılan durumlardan kaynaklanmış olabileceği düşünülmektedir.

Çalışma incelenen VİOP sözleşmesinin getiri, işlem hacmi ve volatilite bazındaki dinamiklerini ortaya çıkararak portföy yöneticilerinin performanslarını artırmalarına, riskten kaçınmak isteyen yatırımcıların risklerini yönetebilmelerine katkı sağlayabilir. Diğer bir deyişle piyasa aktörleri makroekonomik ve finansal bilgiler yardımıyla getirilerini artırabilir. Bununla beraber çalışmanın sayılan hususlar doğrultusunda literatüre de katkıda bulunacağı düşünülmektedir.

Bundan sonra yapılacak olan çalışmalarda farklı vadeli işlem sözleşmeleri incelenebilir ya da incelenen dönem aralığı değiştirilerek/genişletilerek aynı vadeli işlem sözleşmesi yeniden analiz edilebilir.

\section{KAYNAKLAR}

Aktaş, Metin - Akdağ, Saffet (2013), “Türkiye'de Ekonomik Faktörlerin Hisse Senedi Fiyatları İle İlişkilerinin Araştırılması”, International Journal of Social Science Research, 2(1), ss. 50-67.

Albeni, Mesut - Demir, Yusuf (2005), “Makro Ekonomik Göstergelerin Mali Sektör Hisse Senedi Fiyatlarına Etkisi (İmkb Uygulamalı)",.Muğla Üniversitesi Sosyal Bilimler Enstitüsü Dergisi, (14), ss. 1-18.

Al-Khazali, Osamah. M (2003), “Stock Prices, Inflation, and Output: Evidence From The Emerging Markets”, Journal of Emerging Market Finance, 2(3), ss. 287-314. 
Alpar, Reha (2003), Uygulamalı Çok Değişkenli İstatistiksel Yöntemlere Giriş 1, Cilt: 2, Nobel Yayın Dağıtım, Ankara.

Andersson, Magnus - Hansen, Lars J - Sebestyén, Szabolcs (2006), Which News Moves The Euro Area Bond Market, ECB Working Paper, No. 631, European Central Bank (ECB), Frankfurt.

Basher, Syed A. - Sardorsky, Perry (2006), Oil Price And Emerging Stock Markets. Global Financejournal, 17(2), ss. $224-251$.

Batten, Jonathan A - Ciner, Çetin - Lucey, Brian. M. (2010), “The Macroeconomic Determinants Of Volatility İn Precious Metals Markets”, Resources Policy, 35(2), ss.65-71.

Bollerslev, Tim (1986), “Generalized Autoregressive Conditional Heteroscedasticity”, Journal of Econometrics. 1(31), ss. 307-327.

Brigham, Eugene. F. (2006), Finansal Yönetimin Temelleri (Çev. Ö. Akmut ve H. Sarıslan). Ankara Üniversitesi Rektörlüğü Yayınları, Ankara.

Ceylan, Ali - Korkmaz, Turhan (2008), Finansal Teknikler, Ekin Yayınevi, Bursa.

Chance, Don. M. - Brooks, Robert (2010), Introduction to Derivatives and Risk Management, Cengage Learning, USA.

Cihangir, Mehmet - Kandemir, Tuğrul (2010), “Finansal Kriz Dönemlerinde Hisse Senetleri Getirilerini Etkileyen Makroekonomik Faktörlerin Arbitraj Fiyatlandırma Modeli Aracılığıyla Saptanmasına Yönelik Bir Çalışma (Kasım 2000 Ve Şubat 2001 Finansal Krizleri Üzerine Değerlendirme Ve Gözlemler)”, Süleyman Demirel Üniversitesi İktisadi ve İdari Bilimler Fakültesi Dergisi, 5(1), ss. 257-296.

Chevallier, Julien (2009), "Carbon Futures and Macroeconomic Risk Factors: A View From The EU ETS”, Energy Economics, 31(4), ss. 614-625.

Chia, Ricky. C. J. - Lim, Shiok. Y (2015), "Malaysian Stock Price And Macroeconomic Variables: Autoregressive Distributed Lag (ARDL) Bounds Test. Journal of Malaysian Studies”, 33(1), ss. 85-103.

Clare, Andrew - Courtenay, Roger (2001), "What Can We Learn About Monetary Policy Transparency From Financial Market Data?”, Discussion paper 06/01 Economic Research Centre of the Deutsche Bundesbank.

Coşkun, Metin - Kiracı, Kasım - Muhammed, Usman (2016), "Seçilmiş Makroekonomik Değişkenlerle Hisse Senedi Fiyatları Arasındaki İlişki: Türkiye Üzerine Ampirik Bir İnceleme", Finans Politik \& Ekonomik Yorumlar, 24 (616), ss. 61-74.

Çelik, İsmail (2012), Vadeli İşlem Piyasasında Fiyat Keşfi: İzmir Vadeli İşlem Ve Opsiyon Borsasında Ampirik Bir Uygulama, Türkiye Bankalar Birliği, İstanbul. 
Çetin Demir, Gizem (2015), Endeks Vadeli İşlem Sözleşmelerini Etkileyen Makroekonomik Faktörlerin Analizi: Türkiye Uygulaması (Yayınlanmamış Yüksek Lisans Tezi), Marmara Üniversitesi Sosyal Bilimler Enstitüsü, İstanbul.

Durmuş, Savaş - Y1lmaz, Tuncer - Şahin, Dilek (2019), "Makro Ekonomik Göstergelerin Endeks Getirileri Üzerindeki Etkisi: Bist Örneği”, Avrasya Uluslararası Araştırmalar Dergisi, 7(16), ss. 870-886.

Ederington, Louis. H. - Lee, Jae. H. (1993), "How Markets Process İnformation: News Releases And Volatility”, The Journal of Finance, 48(4), ss.1161-1191.

Kırbaş-Kasman, Saadet (2006), "Hisse Senetlerinin Fiyatları Ve Makroekonomik Değişkenler Arasında Bir İlişki Var Mı?” İktisat İşletme ve Finans. 21(238), ss. 88-99.

Kocabıyık, Turan - Fattah, Aram S. (2020), "Makroekonomik Değişkenlerin Borsa Endeksleri Üzerine Etkisi: Türkiye ve ABD Karşılaştırması". Finansal Araştırmalar Ve Çalışmalar Dergisi, 12 (22), ss. 116-151.

Pen, Yannick - Sévi, Benoît (2011), Macro Factors İn Oil Futures Returns, International Economics, (126), ss. 13-38.

Perçin, Merve (2019), Türkiye'de Hisse Senedi Piyasasını Etkileyen Makroekonomik Faktörlerin Analizi, (Yayınlanmamış Yüksek Lisans Tezi), İstanbul Üniversitesi Sosyal Bilimler Enstitüsü, İstanbul.

Liu, Shouwei - Tse, Yiu K. (2013), "Estimation Of Monthly Volatility: An Empirical Comparison Of Realized Volatility, GARCH And ACD-ICV Methods". "www. ink.library.smu.edu.sg.” (Erisim Tarihi:25.01.2019).

Özdemir, Letife. (2017, September), "Vadeli İşlem Piyasası İle Makroekonomik Değişkenler Arasındaki İlişki: Türkiye'de Bir Uygulama”, In Proceedings of 2 nd International Conference on Scientific Cooperation for the Future in the Economics and Administrative Sciences.

Özgümüş, Hasibe - Korkmaz, Turhan - Çevik, E. İ. (2013), "Makroekonomik Faktörlerin Vadeli İşlem (Futures) Sözleşmelerine Etkisi: Vob’ta Bir Uygulama”, BDDK Bankacılık ve Finansal Piyasalar Dergisi, 7(1), ss. 103-136.

Tar1, Recep (2012), Ekonometri, Umuttepe Yayınları, Kocaeli.

Vrugt, Evert B (2010), “Asymmetries in The Reaction of Treasury Bond Futures Returns to Macroeconomic News,” http://www.evertvrugt.com, (Erisim Tarihi:25.01.2019).

Zügül, Muhittin - Şahin, Cumhur. (2009), “IMKB 100 Endeksi İle Bazı Makroekonomik Değişkenler Arasındaki İlişkiyi İncelemeye Yönelik Bir Uygulama”, Akademik Bakış, 16, ss. 1-16. 
Ek 1. Durağanlık Analizi

\begin{tabular}{|c|c|c|c|c|c|c|c|c|c|c|c|c|}
\hline \multirow{3}{*}{ DEĞİŞKENLER } & \multicolumn{6}{|c|}{ DÜZEY DEĞERLER } & \multicolumn{6}{|c|}{ BİRINCİ FARKLAR } \\
\hline & \multicolumn{2}{|l|}{ ADF } & \multicolumn{2}{|l|}{ PP } & \multicolumn{2}{|l|}{ KPSS } & \multicolumn{2}{|l|}{ ADF } & \multicolumn{2}{|l|}{ PP } & \multicolumn{2}{|l|}{ KPSS } \\
\hline & Sabit & Sabit+Trend & Sabit & Sabit+Trend & Sabit & $\begin{array}{l}\text { Sabit+Tren } \\
\text { d }\end{array}$ & Sabit & Sabit+trend & Sabit & $\begin{array}{l}\text { Sabit+Tren } \\
\text { d }\end{array}$ & Sabit & Sait+Trend \\
\hline $\mathbf{R}_{\text {Viop30,t }}$ & $-6.760041^{* * *}$ & $-6.872579^{* * *}$ & $-6.690630^{* * *}$ & $-7.416616^{* * *}$ & $0.235143^{* * *}$ & $0.114341^{* * *}$ & - & - & - & - & - & - \\
\hline 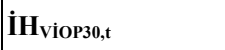 & $-7.978956^{* * *}$ & $-7.982589^{* * *}$ & $-14.72824^{* * *}$ & $-15.30457^{* * *}$ & $0.105862^{* * *}$ & $0.102502^{* * *}$ & - & - & - & - & - & - \\
\hline $\mathrm{V}_{\text {Viop30,t }}$ & $-3.665359^{* * *}$ & $-4.661548^{* * *}$ & $-3.572708^{* * *}$ & $-4.600195^{* * *}$ & $0.520866^{* * *}$ & $0.062054^{* * *}$ & & & & & & \\
\hline BA/GSYİHt & $-11.80656^{* * *}$ & $-11.96212^{* * *}$ & $-15.05761^{* * *}$ & $-15.56709^{* * *}$ & $0.225764^{* * *}$ & $0.064472^{* * *}$ & - & - & - & - & - & - \\
\hline SÜEt & 0.637128 & $-6.800911^{* * *}$ & $-3.186529^{* *}$ & $-6.720338^{* * *}$ & 1.069584 & $0.093176^{* * *}$ & - & - & - & - & - & - \\
\hline ALTINt & $-5.760116^{* * *}$ & $-6.314361^{* * *}$ & $-6.869786^{* * *}$ & $-8.681225^{* * *}$ & $0.444156^{* *}$ & $0.174217^{* * *}$ & - & - & - & - & - & - \\
\hline CA/GSYIHt & $-3.763284^{* * *}$ & $-4.360000^{* * *}$ & $-3.705402^{* * *}$ & $-4.377043^{* * *}$ & $0.718075^{* * *}$ & $0.210295^{* * *}$ & - & - & - & - & - & - \\
\hline TÜFEt & $-5.268485^{* * *}$ & $-5.408357^{* * *}$ & $-7.099336^{* * *}$ & $-7.212937^{* * *}$ & $0.119278^{* * *}$ & $0.044657^{* * *}$ & - & - & - & - & - & - \\
\hline FAİZt & -1.617721 & -1.576532 & -1.771583 & -1.726365 & $0.166678^{* * *}$ & $0.169129^{* * *}$ & $-6.792124^{* * *}$ & $-6.774180^{* * *}$ & $-6.792124^{* * *}$ & $-6.774180^{* * *}$ & $0.114201^{* * *}$ & $0.072429^{* * *}$ \\
\hline LIHRACATt & $-6.088130^{* * *}$ & $-6.051937^{* * *}$ & $-6.166190^{* * *}$ & $-6.130255^{* * *}$ & $0.205274^{* * *}$ & $0.194364^{* * *}$ & - & - & - & - & - & - \\
\hline LITHALATt & -2.154532 & - 2.074842 & $-3.574059^{* * *}$ & $-3.832058^{* *}$ & 0.915156 & 0.218617 & $-7.997701^{* * *}$ & $-8.038984^{* * *}$ & $-14.87645^{* * *}$ & $-16.46373^{* * *}$ & $0.215999^{* * *}$ & $0.151215^{* * *}$ \\
\hline LPARAARZIt & -0.625400 & - 2.665401 & -0.644684 & -2.768932 & 0.967157 & $0.068633^{* * *}$ & $\mid-7.099984^{* * *}$ & $-7.059918^{* * *}$ & $-7.076984^{* * *}$ & $-7.034583^{* * * *}$ & $0.076919^{* * * *}$ & $0.062437^{* * * *}$ \\
\hline VIXt & $-11.16807^{* * *}$ & $-11.11815^{* * *}$ & $-21.99022^{* * *}$ & $-32.86138^{* * *}$ & $0.500000^{* * *}$ & 0.500000 & - & - & - & - & - & - \\
\hline PETROLt & $-6.446932^{* * *}$ & $-6.598031^{* * *}$ & $-6.431563^{* * *}$ & $-6.661518^{* * *}$ & $0.268343^{* * *}$ & $0.139153^{* * *}$ & - & - & - & - & - & - \\
\hline
\end{tabular}

